\title{
French geneticists raise worries over use of new genome funds
}

[PARIS] Many French geneticists and some stock-market analysts are concerned that the government may be planning to prop up the biotechnology company Genset. They suspect that a FF1.5 billion (US\$240 million) boost to genome research, reported to be under consideration by the French government, may represent a hidden subsidy to the ailing French company.

Shares in Genset, the largest biotechnology company in Europe and often called the 'jewel' of French biotechnology, have dropped sharply over the past twelve months from almost $\$ 40$ to around $\$ 15$. The company, valued last summer at over $\$ 700$ million, is now worth about half of this.

Genset's change in fortune has - according to several analysts - been largely prompted by market anticipation of the recent creation of a private-public sector consortium that would map and make freely available variations in the human genetic code linked to diseases. Genset's core business is to find and patent gene-sequence mutations involved in common diseases.

Pascal Brandys, chief executive officer of Genset, disputes this interpretation. He says the drop is "conjectural" and that other biotechnology companies are having the same experience.

He claims that Internet companies, for example, are drawing away investment from the sector and predicts that Genset's troubles are "provisional".

Whatever the explanation, information from a number of sources suggests that the company is likely to be the prime beneficiary of a possible FF1.5 billion injection of state

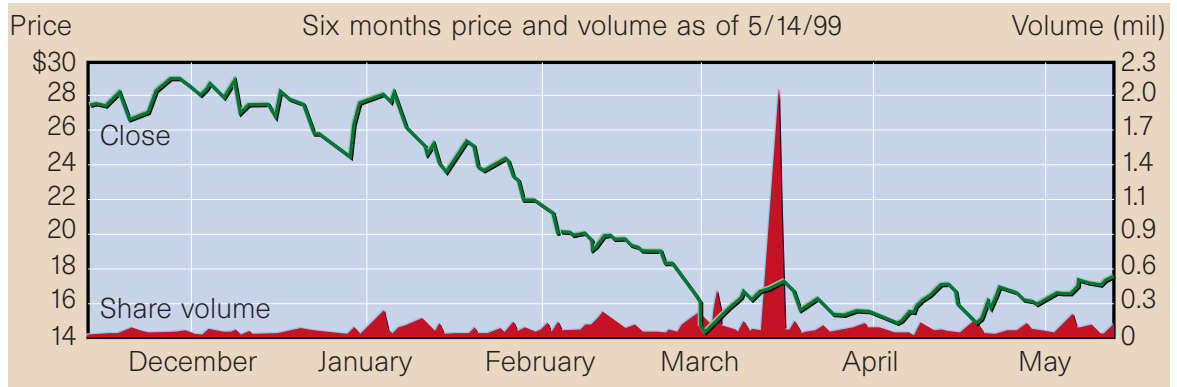

Falling fortunes: the popularity of Genset, the 'jewel' of French biotechnology, has dropped sharply.

funding into genome research.

The government is believed to be examining a proposal that would result in these funds being paid to a consortium made up of Genset, the Institute of Genetics and Molecular Biology near Strasbourg, the Génopôle biotechnology park being built at Evry, near Paris, and the Evry-based National Sequencing Centre (Genoscope) and National Genotyping Centre.

According to several sources, the proposal may give almost half the funds to Genset. Vincent Courtillot, director general of research at the science ministry, declines to confirm or deny this account.

"No public announcement has been made, particularly no numbers given, in any case by our ministry," says Courtillot. "Our prime minister has clearly said that France intends to hold its rank in genome-related innovation, through an alliance between public and private funds. But no other precise numbers are available yet."

Indeed, while France pioneered early genome efforts - its Généthon laboratory

\section{Big boost demanded for France's life sciences}

[PARIS] An expert panel set up by the French government is likely to advise prime minister Lionel Jospin next month to create a multi-billion-dollar life sciences programme. It is expected to aim at linking scientists and industrialists in a coordinated national effort.

The proposal is also expected to call for the creation of a research agency dedicated to genome and molecular research related to therapeutics, along the lines of the French Atomic Energy Commission (CEA). The idea is to repeat in life sciences the success of the CEA, which has helped France to become a world leader in nuclear energy technology.

The panel, called Research and Medicines, is expected to submit its proposals for a national strategy for the scientific and economic development of the life sciences to Jospin within the next two weeks.

Bernard Pau, a member of the panel, declined to confirm its specific recommendations before they were given to the government. He said: "We need to decide on a very big investment in big biology. The life sciences will be one of the big industrial strategic activities of the next century".

Pau sees a need for France and Europe to put biology on the same footing as the French-led European aerospace programmes, such as the commercial Airbus project.

"I want to see the birth of a biotech Airbus," he says, adding that he is "optimistic" about the government's response to funding a major programme.

D.B. published the first physical and genetic maps of the human genome in 1992 (see Nature 359 ; 794; 1992) — such research has until recently languished through lack of support from successive governments.

Pierre Chambon, head of the Strasbourg Institute of Genetics and Molecular Biology that was built in 1994 with the support of Bristol-Myers Squibb, confirms that the FF1.5 billion proposal is under discussion, but says that no decision has yet been taken. He denies, however, that the proposal is intended to indirectly subsidize Genset.

"If I take part in an operation, it is not to refloat Genset, it is because it is worthwhile," says Chambon, who is rumoured to be a candidate to head any consortium. "The essence of the project is outside Genset."

But many geneticists are concerned by what they claim is a lack of openness in the discussions surrounding the proposal, alleging that the decisions are being reached behind closed doors.

This has further fuelled suspicions that the proposal may partly represent a hidden subsidy to Genset.

"It is very worrying," says one leading geneticist. "Government money should not be used to compensate for the industrial risks taken by Genset — risks that have been punished by the market." This view is shared by several other prominent geneticists.

"It is obvious that, as the principle industrialist in this sector, we will take part in any initiative in this area," says Brandys.

He dismisses assertions that its involvement would amount to a subsidy, arguing that state support until now represents only a few per cent of the $\$ 1$ billion it has raised on the stock market. "One can't say we are big consumers of public aid," responds Brandys.

If the company did receive a substantial injection of cash through the proposed consortium, the state would also benefit in terms of contracts and work carried out, according to Brandys.

"There would be positive effects for 
Génopôle and for society at large," he says.

Support for a role for Genset comes from Eric Molinie, an official at the French Muscular Dystrophy Association. The charity has invested more than FF1 billion in the Evry Génopôle and was the largest funder of French genome research before it shifted its focus in the mid-1990s to gene therapy.

The consortium proposal is "a good way to unite public and private genome research", says Molinie, arguing that that there are few genome companies in Europe with the size and expertise of Genset. The consortium would allow France to recapture the lead it has lost in genomics, he says.

But Charles Auffray, a leading French genome researcher, says that - while there is a clear need to relaunch genome research in France - he prefers an integrated approach that would assemble a broad spectrum of public and private bodies within a comprehensive pre-competitive programme. Discussions on the way forward need to be more open, says Auffray.

The need for a broad approach is also supported by Bernard Pau, director of biotechnology policy at the Centre National de la Recherche Scientifique, and a member of a panel set up by the government to recommend a new national strategy for life sciences (see previous page).

Pau argues that genome research itself is increasingly seen as being less important than post-genome research areas. This view seems to be shared by the markets.

Genomics is now considered to be a "lowprice commodity", says Genghis LloydHarris, director of equity research for the pharmaceutical and biotechnology sectors at the investment bank, Credit Suisse First Boston.

"The market is more interested in postgenome research, such as proteomics and DNA chip technology, which it sees as being more directly related to drug discovery," says Lloyd-Harris.

Such reasoning is one explanation for market dissatisfaction with Genset. A more immediate cause for the fall in its shares, suggests Ernie Knewitz, from Noonan-Russo Communications - Genset's public relations firm - is the recent decision by ten of the world's leading pharmaceutical companies and Britain's Wellcome Trust to fund a US\$45-million map of the variations in the human genetic code linked to common diseases (see Nature 398, 545; 1999).

By agreeing not to patent the map and to make it freely available, the group has implicitly challenged Genset's core business, namely mapping such single-nucleotide polymorphisms (SNPs) and striking alliances with pharmaceutical companies. One industry analyst says the new initiative turns SNP mapping into "pre-competitive research".

Knewitz points out that Michael King, an analyst at Robertson Stevens, has reiterated the firm's "buy rating" on Genset, in the belief that the company has a large head start on the consortium and should complete its own proprietary map by the end of the year. "Investor concerns have been overplayed," says the text accompanying the rating. "The high level of interest in SNPs validates the Genset approach.”

But one analyst expresses concern that Genset failed to live up to its "emphatic promises on milestones in terms of the number of SNPs mapped. The market was angry in feeling that it was misled."

Brandys vehemently denies this, arguing that numbers of SNPs or progress in mapping are irrelevant. The wider system for gene discovery is what counts, he says, including large-scale genotyping and analytical methods. "We have always been prudent in our claims," he asserts. "All that counts is our portfolio of patents. Our only milestone is gene discovery."

But the analyst adds that Genset pales besides rivals such as Celera, set up by genome pioneer Craig Venter, "which has patented thousands of genes and has three of its own products in clinical trials".

The market response to any new government support for Genset is unpredictable. "We are working on the assumption that Genset will get a whole lot of money," says one analyst.

DeclanButler

\section{Increase in German science budget a boon for women and youth}

[MUNICH] Germany's coalition government, which made a pre-election promise to double research spending within five years, has approved an 11 per cent rise in the 1999 science budget.

The increase brings the science budget to nearly DM15 billion (US $\$ 8.2$ billion). The new money will be primarily used to support research in biotechnology and information sciences (see Nature 398, 7; 1999). In biotechnology and molecular medicine, for example, an additional DM233 million will be made available in project money, and a new programme on the plant genome will belaunched.

It will also be used to secure Germany's future scientific base by improving career prospects for young scientists and women. For example, it will pay for a new postgraduate programme, the Emmy Noether programme - named after a famous German female mathematician - launched this year by the Deutsche Forschungsgemeinschaft (DFG), Germany's university grant-making agency.

The programme supports young scientists, who must be under 30 when they apply, to complete two years of research abroad and then return to Germany to set up a university research group. The group's operating costs will be covered for three years. Normally, German scientists are well into their forties before

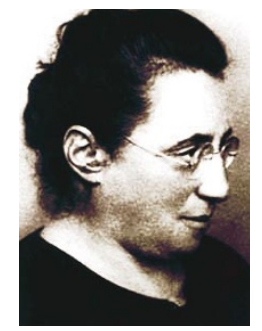

Noether: inspires a new programme. they have the opportunity to direct their own research group.

The Emmy Noether programme has been allocated DM14 million for the current year, but this will rise to DM60 million a year as the number of researchers supported grows.

The extra money will also be used to launch a DM7.5 million programme of special measures to promote women's career prospects. These include special coaching programmes for women identified as talented during postdoctoral work.

These coaching programmes will be designed to "prepare women for competition for senior posts - particularly in strongly male-dominated areas like information science - before they disappear from science for ever", says a ministry spokeswoman.

But she points out that measures to promote equality of opportunity for women are not "ghettoized" in this new programme — all ministry programmes will be regularly audited to assess efforts to promote equality. "The spirit pervades the whole ministry," she says.

The same spirit will permeate most of
Germany's research organizations. For example, the DFG's Emmy Noether awards can be used in part to pay for child care. Recipients may choose to work part-time for an extended period to allow them to build a family.

Moreover, in plans drawn up between the ministry and the Helmholtz Society (the umbrella group of Germany's 16 large national research centres), the society has pledged to promote 100 women to top positions in its research centres in the next few years. The Research Centre Jülich has already started an active recruiting campaign (see Nature 398, $550 ; 1999)$.

Other measures include support of an International Women's University that will be established for 100 days during next summer's EXPO in Hanover. One thousand women from around the world will attend the university to teach and carry out research on seven themes: the city, work, migration, the body, intelligence, the information society, and water.

The ministry's new money also increases by DM200 million the federal government's contribution to university building and large equipment, which has been capped at DM1.8 billion for years. Germany's Science Council, the Wissenschaftsrat, has long complained that the building programme was dangerously underfunded.

Alison Abbott 